\title{
The Fungal Endophyte Serendipita williamsii Does Not Affect Phosphorus Status But Carbon and Nitrogen Dynamics in Arbuscular Mycorrhizal Tomato Plants
}

\author{
Anna M. Hallasgo ${ }^{1}$, Bernhard Spangl ${ }^{2} \mathbb{D}$, Siegrid Steinkellner ${ }^{1}$ and Karin Hage-Ahmed ${ }^{1, *}$ (i) \\ 1 Department of Crop Sciences, Institute of Crop Protection, University of Natural Resources and Life Sciences, \\ Vienna, 3430 Tulln, Austria; anna.hallasgo@boku.ac.at (A.M.H.); siegrid.steinkellner@boku.ac.at (S.S.) \\ 2 Department of Landscape, Institute of Statistics, Spatial and Infrastructure Sciences, University of Natural \\ Resources and Life Sciences, Vienna, 1180 Vienna, Austria; bernhard.spangl@boku.ac.at \\ * Correspondence: karin.hageahmed@boku.ac.at; Tel.: +43-1-476-549-5305
}

Received: 29 September 2020; Accepted: 16 October 2020; Published: 19 October 2020

\begin{abstract}
Some members of the root endophytic Serendipitaceae were observed to frequently coexist with arbuscular mycorrhizal fungi (AMF), but their interactions and potential synergistic effects in plants have not yet been well elucidated. Here, we inoculated three-week-old tomato seedlings with Serendipita indica or Serendipita williamsii alone or in combination with the arbuscular mycorrhizal fungus Funneliformis mosseae and cultivated the plants in a greenhouse until the late vegetative stage. Our data show that the simultaneous presence of Serendipita spp. did not affect root colonization by AMF, proving the feasibility of their combination for future agronomic uses. The photosynthetic performance was enhanced in AM tomato plants, although growth remained unresponsive following single or dual inoculation with Serendipita spp. and AMF. With regard to nutrient status under dual inoculation, AMF-induced phosphorus increases remained unaffected, but nitrogen and carbon dynamics were highly altered. Specifically, the application of $S$. williamsii to mycorrhizal tomato plants significantly enhanced nitrogen concentration in the shoots, but this effect was also compensated with a carbon cost. Our findings indicate that $S$. williamsii performs differently from $S$. indica when co-inoculated with AMF, and this suggests an unknown mechanism that needs more detailed investigation.
\end{abstract}

Keywords: arbuscular mycorrhizal fungi; endophytes; Serendipita; phosphorus; nitrogen; carbon; coexistence; tomato

\section{Introduction}

The rhizosphere is a habitat for a myriad of microorganisms including bacteria and fungi, where multipartite interactions take place [1,2]. While some microorganisms can inhabit plant roots and cause detrimental effects [3], others can boost performance of the host [4]. In particular, they can help overcome biotic and abiotic stress, as well as improve growth and nutrition in plants $[5,6]$. These microorganisms that are also ubiquitous in the environment include arbuscular mycorrhizal fungi (AMF) and root endophytic Serendipitaceae $[4,7,8]$.

The association between plants and AMF remains one of the most essential examples of symbiosis between living organisms [9]. As predominant soil microorganisms, AMF are able to colonize the roots of more than $80 \%$ of terrestrial plants [10]. This AM symbiosis is characterized by a bidirectional relationship: Plants receive relatively immobile nutrients from the soil through the extensive hyphal network of AMF in exchange for photosynthetically fixed carbon [10-14]. Apart from the nutritional benefits, AMF can also enhance growth $[15,16]$ and alleviate disease stress in plants $[17,18]$. 
In contrast, Serendipitaceae, are a recently described group of root fungal endophytes, known for their plant growth promoting properties [19]. Unlike AMF, Serendipita spp. grow in synthetic media and proliferate in root tissue independent of the phosphorus levels in the soil $[19,20]$. Two out of four recently described members of this fungal group were originally recovered from independent pot cultures of AMF [19,21]. The most well-studied member is Serendipita indica (syn Piriformospora indica), isolated from an AM fungal spore of Funneliformis mosseae (syn. Glomus mosseae), retrieved from the rhizosphere of Prosopis juliflora and Zizyphus nummularia in Northwest India [19]. Several reports have documented the ability of $S$. williamsii to colonize roots and consequently enhance growth [20,22-25], as well as ameliorate biotic [26-30] and abiotic stress in plants [31-34]. A lesser known relative of S. indica is Serendipita williamsii (syn. Piriformospora williamsii), which was isolated from a fungal spore of the AM fungus Rhizophagus fasciculatus (syn. Glomus fasciculatum) associated with clover roots [21]. In recent studies, S. williamsii surpassed the growth promoting activity of S. indica in A. thaliana [4] and also improved growth in tomato plants [22].

In an earlier study, Williams [21] uncovered an intimate association in which he detected chlamydospores of the previously recognized multinucleate Rhizoctonia-like isolates (recently identified as S. williamsii) inhabiting the intracellular structure of an AM fungus. Several decades later, other researchers reaffirmed this finding when they observed the frequent coexistence of Serendipita isolates with AMF in the roots of sudangrass during a trap system experiment [4]. Interestingly, single inoculation with S. williamsii did not promote growth in pasture legumes and ryegrass plants, but an increase of the parameter was observed when AMF was present in the system [21]. Simultaneous inoculation with S. indica and AMF also resulted in growth and nutrient stimulating effects in tomato plants even under salinity stress [35]. The coexistence between endophytic and mycorrhizal fungi involves a putative intimate relationship and understanding their interactions might open a window of opportunity to develop an inoculum that exceeds the outcome of a single inoculation [4].

In our study, we aimed to further investigate the coexistence between S. indica or S. williamsii and AM fungus $F$. mosseae and to elucidate their potential synergistic effects in tomato plants, a well-known host for both fungi [35]. We hypothesized that the combination of endophytic and mycorrhizal fungi would influence AMF root colonization, growth, photosynthetic activity, and nutrient status in tomato plants.

\section{Materials and Methods}

\subsection{Fungal Material and Inoculum Production}

Serendipita species, including Serendipita indica (DSM 11827) and S. williamsii (DAR 29830), kindly provided by Michael Weiß (University of Tübingen, Germany), were propagated on a modified Hill and Käfer Medium [36] in the dark at $24^{\circ} \mathrm{C}$. To produce the inoculum, small plugs of four-week old cultures were transferred in $250 \mathrm{~mL}$ Erlenmeyer flasks containing $150 \mathrm{~mL}$ of liquid Hill and Käfer Medium and incubated in an orbital shaker for three weeks in the dark at $24^{\circ} \mathrm{C}$. Fungal cultures were filtered and homogenized using a high speed blender, three times, for $30 \mathrm{~s}$ each. Subsequently, the homogenized mycelial fragments were centrifuged at $4000 \mathrm{rpm}$ for five minutes at room temperature. The supernatant was discarded, and the pellets were washed with autoclaved $\mathrm{dH}_{2} \mathrm{O}$. The concentration of the mycelial fragments was determined using a Fuchs-Rosenthal hemocytometer and adjusted to $3 \times 10^{5} \mathrm{cfu} \cdot \mathrm{mL}^{-1}$ of autoclaved $\mathrm{dH}_{2} \mathrm{O}$ [24]. To verify the viability of the fungal propagules, inoculum suspensions of Serendipita spp. were plated in a solidified Hill and Käfer Medium and incubated at $24^{\circ} \mathrm{C}$.

The AMF inoculum was produced in the greenhouse using Plantago lanceolata $\mathrm{L}$. as a host plant. Propagules of Funneliformis mosseae (BEG 12) were inoculated into pots containing a mixture of sand (Quarzsand 0-3 mm, Quarzwerke Österreich GmbH, Melk, Austria), expanded clay (Seramis, Seramis $\mathrm{GmbH}$, Mogendorf, Germany) $(1: 1, v / v)$, and seeds of P. lanceolata. The plants were grown in a greenhouse for several months, and the roots were regularly checked for AMF colonization. A mixture of the AMF colonized substrate (spores, hyphae, sand, and expanded clay) and root fragments of P. lanceolata was used as the AMF inoculum. 


\subsection{Plant Material, Inoculation, and Cultivation}

Seeds of tomato (Solanum lycopersicum L. cv. "Kremser Perle") were surface-sterilized with diluted household bleach $(1.4 \% \mathrm{NaClO})$ for ten minutes and then rinsed three times with autoclaved $\mathrm{dH}_{2} \mathrm{O}$. The surface-sterilized seeds were sown into pots filled with double autoclaved perlite (Granuperl S 3-6, Knauf Perlite $\mathrm{GmbH}$, Vienna, Austria) and cultivated in a growth chamber at $24^{\circ} \mathrm{C}$ with a $14 \mathrm{~h}$ photoperiod.

After three weeks, the seedlings were characterized by the appearance of the first true leaf and then harvested from the perlite. Next, the roots were soaked in the Serendipita spp. inoculum suspension

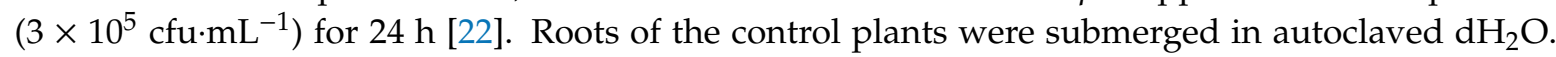
After $24 \mathrm{~h}$, the sample roots were stained with an ink-vinegar solution [37] to confirm root colonization by Serendipita spp. Prior to transplanting, $10 \mathrm{~mL}$ of the AMF inoculum was added to the planting hole of the AMF treated plants (+AMF). Non-mycorrhizal (-AMF) pots obtained $10 \mathrm{~mL}$ of microbial wash to correct potential differences in their microbial communities [38]. The microbial wash was produced by wet sieving a mixture containing the AMF inoculum and $\mathrm{dH}_{2} \mathrm{O}(1: 6, v / v)$ through a $38 \mu \mathrm{m}$ sieve.

Seedlings were transplanted in $10 \mathrm{~cm}$ pots filled with soil (Aussaaterde, Gramoflor GmbH \& Co. KG, Vechta, Germany), sand (Quarzsand 0-3 mm, Quarzwerke Österreich GmbH, Melk, Austria), and clay (Liapor fit 1-4 mm, Lias Österreich GmbH, Fehring, Austria) (1:1:1, v/v/v). The substrate had a $\mathrm{pH}$ of 6.56 and contained the following elemental concentrations in $\mathrm{kg}^{-1}$ soil: $25.86 \mathrm{mg} \mathrm{P}, 68.97 \mathrm{mg} \mathrm{K}, 123.49 \mu \mathrm{g}$ $\mathrm{Fe}, 11.22 \mu \mathrm{g} \mathrm{Mn}$, and $0.97 \mu \mathrm{g} \mathrm{Zn}$. Each plant received $30 \mathrm{~mL}$ of standard low phosphorus nutrient solution per week starting from the second week after transplanting, with the following components $\mathrm{L}^{-1}$ : $0.09 \mathrm{~mm} \mathrm{P}, 3.57 \mathrm{~mm} \mathrm{~N}, 1.59 \mathrm{~mm} \mathrm{~K}, 3.07 \mathrm{~mm} \mathrm{Mg}, 3.47 \mathrm{~mm} \mathrm{Ca}, 4.58 \mathrm{~mm} \mathrm{~S}, 98.78 \mu \mathrm{m} \mathrm{Fe}, 4.76 \mu \mathrm{m} \mathrm{B}, 3.79 \mu \mathrm{m}$ $\mathrm{Mn}, 2.09 \mu \mathrm{m} \mathrm{Zn}, 2.09 \mu \mathrm{m} \mathrm{Cu}, 0.49 \mu \mathrm{m} \mathrm{Mo}$, and $3.79 \mu \mathrm{m} \mathrm{Cl}$ [39]. Irrigation with tap water was done twice per week or when needed. The experimental set-up consisted of the following treatments: (i) control, (ii) S. indica and (iii) S. williamsii all with (+AMF) and without AMF (-AMF). Each treatment featured 15 replicate pots with a total number of 90 pots. Plants were grown in the greenhouse and arranged in a randomized complete block design. Day and night temperatures were 24 and $18^{\circ} \mathrm{C}$, respectively, with relative humidity of $60 \%$. A $16 \mathrm{~h}$ photoperiod was used, and additional light was provided when the outside photosynthetically active radiation (PAR) was below $367.43 \mu \mathrm{mol} \mathrm{m}{ }^{-2} \cdot \mathrm{s}^{-1}$.

\subsection{Photosynthetic Performance}

The performance of photosystem II was assessed using a portable chlorophyll fluorometer (PAM 2500, Walz, Germany). The minimal fluorescence yield (Fo), maximal fluorescence yield (Fm), and maximum photochemical quantum yield of photosystem II (Fv/Fm) were measured using the youngest fully expanded leaf of the dark adapted ( $30 \mathrm{~min}$ ) tomato plants.

\subsection{Harvest and Nutrient Analysis of Tomato Shoots}

Tomato plants were harvested nine weeks after transplanting. The fresh weight and length of the shoots and roots were determined. The shoot material was oven-dried at $65^{\circ} \mathrm{C}$, and the dry weight was measured. The roots were then either stored in $50 \mathrm{~mL}$ centrifuge tubes filled with $30 \%$ ethanol and kept at $4{ }^{\circ} \mathrm{C}$ until staining or stored at $-80^{\circ} \mathrm{C}$ until DNA extraction.

Oven-dried tomato shoots were pooled into four samples per treatment. Pooled samples were milled into a fine powder using a Retsch Knife Mill Grindomix GM200 plant mill (Retsch GmbH, Haan, Germany). Thereafter, the samples were dried at $105{ }^{\circ} \mathrm{C}$ prior to elemental analysis. The macronutrients such as phosphorus $(\mathrm{P})$, calcium $(\mathrm{Ca})$, potassium $(\mathrm{K})$, and magnesium $(\mathrm{Mg})$, as well as the micronutrients such as iron $(\mathrm{Fe})$, manganese $(\mathrm{Mn})$, and zinc $(\mathrm{Zn})$ were analyzed by inductively coupled plasma-atomic emission spectroscopy (ICP-OES) Optima 8300 DV (PerkinElmer, Waltham, MA, USA). The ground sample of shoot tissue $\left(200 \mathrm{mg} \pm 10 \mathrm{mg}\right.$ ) was subjected to acid digestion by directly adding $8 \mathrm{~mL}$ of $\mathrm{HNO}_{3}$ in an Xpress microwave vessel (CEM, Buckingham, UK) containing the sample. The next day, $2 \mathrm{~mL}$ of $\mathrm{H}_{2} \mathrm{O}_{2}$ was added to the mixture, and digestion was carried out using the microwave instrument MARS 6 (CEM, Buckingham, UK). Then, the digested solution was diluted to $50 \mathrm{~mL}$ using $\mathrm{dH}_{2} \mathrm{O}$. The analysis 
was performed with ICP-OES using $426 \mathrm{~mL}$ of the diluted sample, $5.72 \mathrm{~mL}$ of $\mathrm{dH}_{2} \mathrm{O}$, and $0.769 \mathrm{~mL}$ of the reference standard.

The carbon and nitrogen ratio $(\mathrm{C} / \mathrm{N})$ was assessed according to the Dumas combustion method [40]. Approximately $10-15 \mathrm{mg}$ of the ground sample was weighed in a tin container and loaded into the Vario Macro Cube automatic sampler (Elementar, Langenselbold, Germany). The combustion tube was filled with the tin containing the sample. Eventually, the combustion started at $960{ }^{\circ} \mathrm{C}$ and accelerated to $1800{ }^{\circ} \mathrm{C}$, thus converting carbon to $\mathrm{CO}_{2}$ and nitrogen to $\mathrm{N}_{2}$. The carbon dioxide and nitrogen were separated and then detected by a thermocouple device.

\subsection{Detection of AMF in Colonized Roots}

AMF structures were visualized using the ink-vinegar staining procedure [37]. Tomato roots were cleared by immersion in $10 \%$ potassium hydroxide $(\mathrm{KOH})$ for five minutes at $90^{\circ} \mathrm{C}$. The roots were rinsed with running tap water to remove the $\mathrm{KOH}$. Afterwards, a $5 \%$ ink-vinegar solution was added to the roots and boiled for $20 \mathrm{~min}$ at $90{ }^{\circ} \mathrm{C}$. Finally, the stained roots were incubated in tap water with few drops of vinegar for $30 \mathrm{~min}$ and then stored in $30 \%$ ethanol until microscopic evaluation.

AMF root colonization was evaluated using the method of McGonigle et al. [41]. The stained roots were cut into small pieces (approximately $1 \mathrm{~cm}$ ), and 15 random samples were mounted onto

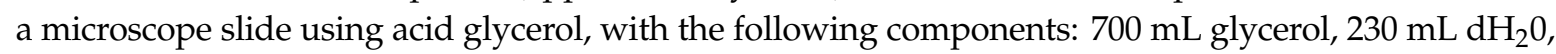
and $70 \mathrm{~mL} \mathrm{1 \%} \mathrm{HCl}$. Two slides per sample (i.e., 30 root pieces), with 100 intersections per slide, were used for the evaluation. To observe the intraradical AMF structures (hyphae, arbuscules, and vesicles), the slide was placed under a light microscope (Olympus BX53) and analyzed using $200 \times$ magnification. To calculate the relative amount of different AMF structures, the following formulae were used:

$$
\begin{gathered}
\% \mathrm{AC}=\frac{\text { number of intersections with the presence of arbuscules }}{\text { total number of intersections examined } \times 100} \\
\% \mathrm{VC}=\frac{\text { number of intersections with the presence of vesicles }}{\text { total number of intersections examined } \times 100} \\
\% \mathrm{TC}=\frac{\text { total number of intersections examined }- \text { negative intersect }}{\text { total number of intersections examined } \times 100}
\end{gathered}
$$

\subsection{DNA Extraction and Detection of Serendipita spp. in Colonized Roots by Nested PCR}

The total DNA of the tomato roots (4 samples per treatment) was extracted from a $\leq 100 \mathrm{mg}$ sample using a DNEasy Plant Mini Kit (Qiagen, Hilden, Germany) according to the manufacturer's instructions. In the first polymerase chain reaction (PCR), $852 \mathrm{bp}$ and $1.1 \mathrm{~kb}$ fragments of the translation elongation factor (TEF) $1-\alpha$ gene of $S$. indica and $S$. williamsii, respectively, were amplified. The primers SiTEF2879f (5'-GTTTCTTTGTCGTCTCGTTC-3') and SiTEF3711r (5'-GAAAATGTGGTGGGTTTACG-3') for the S. indica TEF fragment were designed using the Primer-BLAST algorithm [42] on the TEF 1- $\alpha$ gene (AJ249911.2). For amplification of the fragment of the TEF region of S. williamsii, the primers EF1-0728f [43] and EF1-1620r [44] were used. The total reaction volume in each tube was $25 \mu \mathrm{L}$ and included $18.8 \mu \mathrm{L} \mathrm{ddH}_{2} 0,2.5 \mu \mathrm{L}$ reaction buffer (10×), $0.5 \mu \mathrm{L}$ dNTPs, $0.5 \mu \mathrm{L}$ for each primer, $0.2 \mu \mathrm{L}$ Taq polymerase (Taq DNA Polymerase, VWR, Vienna, Austria), and $2 \mu \mathrm{L}$ DNA template. Amplification was performed in an Eppendorf Nexus GX2 thermocycler (Eppendorf Austria $\mathrm{GmbH}$, Vienna, Austria) with the following cycling parameters: $95^{\circ} \mathrm{C}$ for $2 \mathrm{~min}, 20$ cycles at $95^{\circ} \mathrm{C}$ for $20 \mathrm{~s}, 58^{\circ} \mathrm{C}(\mathrm{Si}) / 54{ }^{\circ} \mathrm{C}(\mathrm{Sw})$ for $30 \mathrm{~s}$, and $72{ }^{\circ} \mathrm{C}$ for $50 \mathrm{~s}$, with a final step at $72{ }^{\circ} \mathrm{C}$ for $5 \mathrm{~min}$. In a second PCR run, smaller areas of the previously amplified TEF fragments were targeted. $S$. indica specific primer pairs (SiTEF3210f 5'-GTGTGTGGAGAGCTACAACGA-3') and SiTEF3210r 5'-CGCGCTCTTCGTAACTGGAA-3') were designed using the Primer-BLAST algorithm [42] on the TEF region (AJ249911.2). For S. williamsii, the portion of the TEF region amplified by the primers TEF420f/TEF420r [45] was sequenced (LGC Genomics $\mathrm{GmbH}$, Berlin, Germany), and thereafter the reverse primer SwTEF1r (5'-GATACAACGCGGGGGAGTTC-3') was designed using the Primer-BLAST algorithm [42]. The primer TEF420f [45] was used as the forward primer for S. williamsii. The reaction volumes and compounds were used as previously described, apart from 
adding $2 \mu \mathrm{L}$ of the diluted PCR product (1:100) from the first PCR. The cycling parameters were similar to those of the first PCR apart from the annealing temperature of $60^{\circ} \mathrm{C}$ and the use of 30 cycles. The presence of amplified PCR products was confirmed using a $2 \%$ agarose gel in a $1 \times$ TAE buffer.

\subsection{Statistical Analysis}

A two-way ANOVA with the fixed factors Serendipita and AMF was performed in the software IBM SPSS Statistics (ver. 26, IBM Incorporation, Armonk, NY, USA). The factor Serendipita had three levels including control, S. indica and S. williamsii while the factor AMF had two levels including - AMF (without AMF) and + AMF (with AMF). Data were checked for homogeneity of variance using Levene's test. In addition, a simple effect test was performed when interaction effects were found to be significant. Moreover, principal component analysis and k-means clustering of the nutrient and AMF root colonization variables were conducted using the package "factoextra" in the R software (ver. 3.6.3, R Foundation for Statistical Computing, Vienna, Austria), as performed in Kalaji et al. [46]. The PCA biplot and the cluster map were produced in R. All other graphs and figures were created using Sigma Plot (ver. 14, Systat Software Inc., San Jose, CA, USA).

\section{Results}

\subsection{Fungal Colonization}

\subsubsection{Root Colonization by AMF}

Three independent ANOVAs were performed for the total, arbuscular, and vesicular root colonization by $\mathrm{AMF}$, and we found no significant differences between treatments for each parameter (Table 1 and Figure 1a). Tomato roots were intensely colonized by AMF (Figure 1b), with a colonization percentage of between 50 and $100 \%$. Moreover, the arbuscular root colonization (Figure 1c) was between 15 and $70 \%$, while the amount of vesicles (Figure 1d) was between 10 and $40 \%$. No AMF structures could be detected in non-mycorrhizal tomato plants.

Table 1. Results of the one-way ANOVA ( $p$-values) for the arbuscular mycorrhizal fungi (AMF) root colonization parameters in tomato plants nine weeks after transplanting $(p<0.05, n=15)$.

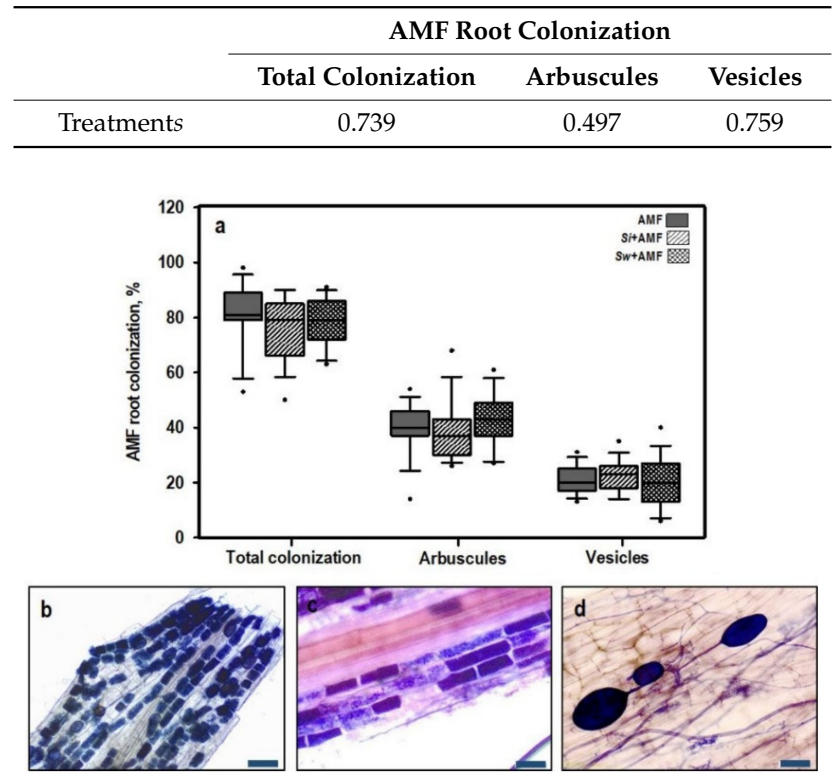

Figure 1. AMF root colonization in tomato roots nine weeks after transplanting including the $\%$ total root colonization, \% arbuscules, and \% vesicles (a). There were no significant differences detected between the treatments (ANOVA, $p<0.05, n=15$ ). Different parts showing an intensely colonized root piece (b), arbuscules (c), and vesicles (d) in the tomato roots. Roots were stained using the ink-vinegar method of Vierheilig et al. [37]. Scale bar: $100 \mu \mathrm{m}(\mathbf{b})$ and $50 \mu \mathrm{m}(\mathbf{c}, \mathbf{d})$. 


\subsubsection{Root Colonization by Serendipita spp.}

Through staining and microscopic confirmation, dense mycelial networks of Serendipita spp. were found on the surface of the tomato roots $24 \mathrm{~h}$ after inoculation. Structures of Serendipita spp., such as chlamydospores of $S$. williamsii (Figure 2a) and chlamydospores of $S$. indica (Figure 2b) in the mycorrhizal tomato plants nine weeks after transplanting, were also observed during the microscopic evaluation. Root colonization by $S$. indica and S. williamsii, respectively, was further confirmed by nested PCR (Figure 2c). S. indica and S. williamsii could be detected in the respective samples. Serendipita spp. were not detected in uninoculated control plants.

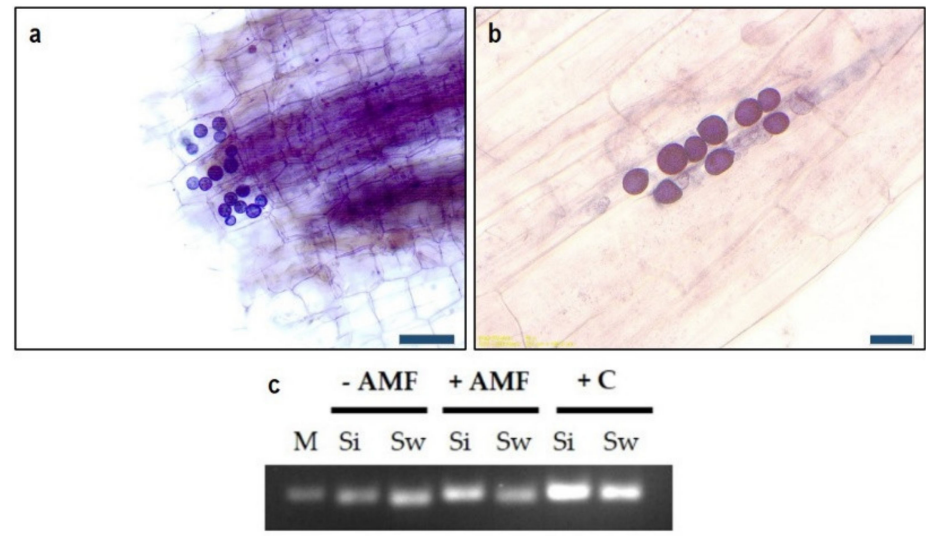

Figure 2. Root colonization by Serendipita spp. including chlamydospores of S. indica (a) and S. williamsii (b) observed in the mycorrhizal roots of tomato plants. Roots were stained using the ink-vinegar method of Vierheilig et al. [37]. Scale bar: $50 \mu \mathrm{m}(\mathbf{a}) ; 20 \mu \mathrm{m}$ (b). Verification of root colonization of S. indica (Si, $189 \mathrm{bp}$ ) and S. williamsii (Sw, 180 bp), respectively, by nested PCR (c). M: marker (200 bp), +C: positive control from pure fungal cultures.

\subsection{Plant Growth and Performance of Photosystem II}

The shoot length and shoot dry weight in tomato plants nine weeks after transplanting were unaffected by the main factors of "Serendipita" and "AMF", as well as the "Serendipita" $\times$ "AMF" interactions (Tables 2 and 3).

Table 2. Results of the two-way ANOVA ( $p$-values) for growth and photosynthetic performance in tomato plants nine weeks after transplanting with the factors 'Serendipita', 'AMF,' and 'Serendipita $\times$ AMF' interactions $(p<0.05, n=15)$.

\begin{tabular}{cccccc}
\hline \multirow{2}{*}{ Factor } & \multicolumn{3}{c}{ Growth } & \multicolumn{2}{c}{ Performance of Photosystem II } \\
\cline { 2 - 6 } & Shoot Length & Shoot Dry Weight & Fo $^{\mathbf{1}}$ & Fm $^{\mathbf{2}}$ & Fv/Fm $^{\mathbf{3}}$ \\
\hline Serendipita & 0.214 & 0.365 & 0.137 & 0.949 & 0.191 \\
AMF & 0.079 & 0.536 & 0.809 & 0.197 & $\mathbf{0 . 0 2 5}$ \\
Serendipita $\times$ AMF & 0.121 & 0.063 & $\mathbf{0 . 0 1 0 ^ { 4 }}$ & $\mathbf{0 . 0 4 5}$ & 0.467
\end{tabular}

${ }^{1} \mathrm{Fo}-$ minimal \& ${ }^{2} \mathrm{Fm}-$ maximal chlorophyll fluorescence yield; ${ }^{3} \mathrm{Fv} / \mathrm{Fm}-$ maximum photochemical quantum yield of photosystem II. ${ }^{4}$ Significant values $(p<0.05)$ are highlighted in bold.

Table 3. Mean values ( \pm S.D.) of the above ground growth of tomato plants nine weeks after transplanting (n=15).

\begin{tabular}{ccc}
\hline \multirow{2}{*}{ Treatments } & \multicolumn{2}{c}{ Growth } \\
\cline { 2 - 3 } & Shoot Length $(\mathbf{c m})$ & Shoot DW $\mathbf{( g )}$ \\
\hline Control & $23.09 \pm 1.32$ & $1.16 \pm 0.25$ \\
S. indica & $24.48 \pm 1.86$ & $1.20 \pm 0.15$ \\
S. williamsii & $22.81 \pm 2.38$ & $1.22 \pm 0.22$ \\
AMF & $22.91 \pm 1.79$ & $1.21 \pm 0.11$ \\
S. indica + AMF & $22.69 \pm 1.69$ & $1.23 \pm 0.13$ \\
S. williamsii + AMF & $22.76 \pm 1.61$ & $1.07 \pm 0.15$ \\
\hline
\end{tabular}


The main factor Serendipita did not affect the chlorophyll fluorescence parameters ( $\mathrm{Fo}$, Fm, and Fv/Fm) (Table 2). However, the main factor AMF had a significant influence on the maximum photochemical quantum yield of photosystem II $(\mathrm{Fv} / \mathrm{Fm})\left(F_{(1,84)}=5.246, p=0.025\right)$. The $\mathrm{Fv} / \mathrm{Fm}$ values of AMF inoculated plants (+AMF) were significantly higher than those of non-mycorrhizal plants (-AMF) (Figure 3a). The highest level was observed when S. indica was co-inoculated with AMF compared to plants singly inoculated with the endophyte. In addition, a simple effect test was conducted on the minimal chlorophyll fluorescence $(\mathrm{Fo})$ yield because the statistical test showed a significant interaction between Serendipita $\times$ AMF $\left(F_{(2,84)}=4828, p=0.010\right)$ (Table 2). The significant interaction was represented by a higher Fo in S. indica treated plants than the control in the -AMF treatment. An increase in Fo in S. williamsii + AMF treated plants was also observed compared to both the control with AMF and S. indica + AMF inoculated plants (Figure 3b). A significant interaction effect between Serendipita and AMF was found in the maximum chlorophyll fluorescence (Fm), but the simple effect test yielded no significant differences between the different levels of the main fixed factors.
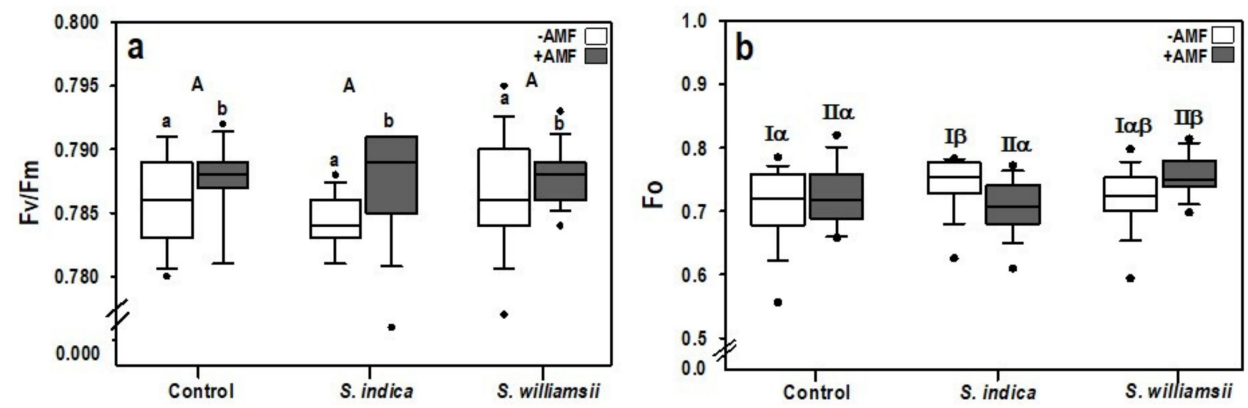

Figure 3. Chlorophyll fluorescence parameters including the maximum photochemical quantum yield of photosystem II (Fv/Fm) (a) and the minimal chlorophyll fluorescence yield (Fo) (b). Upper-case letters indicate differences in the main factor 'Serendipita'. Lower-case letters indicate differences in the main factor 'AMF' (ANOVA, $p<0.05, n=15$ ). Greek letters were used to highlight significant interaction effects based on the simple effect analysis for -AMF(I) and +AMF(II). Columns followed by the same letters are not significantly different.

\subsection{Nutrient Status in Tomato Shoot}

\subsubsection{Macronutrients}

Phosphorus concentration was significantly affected by the factor $\operatorname{AMF}\left(F_{(1,18)}=12.412, p=0.002\right)$ (Table 4). This influence was characterized by a 13\% increase in $P$ concentration in the +AMF compared to the -AMF plants (Figure 4a). The factors Serendipita and Serendipita $\times$ AMF did not affect the P status in tomato plants.

Table 4. Results of the two-way ANOVA ( $p$-values) for macronutrient concentrations in tomato shoots nine weeks after transplanting with the factors 'Serendipita', 'AMF', and 'Serendipita $\times \mathrm{AMF}^{\prime}$ interaction $(p<0.05, n=4)$.

\begin{tabular}{cccccccc}
\hline \multirow{2}{*}{ Factor } & \multicolumn{7}{c}{ Macronutrients } \\
\cline { 2 - 8 } & $\mathbf{P}$ & $\mathbf{C a}$ & $\mathbf{M g}$ & $\mathbf{K}$ & $\mathbf{C}$ & $\mathbf{N}$ & $\mathbf{C N}$ \\
\hline Serendipita & 0.281 & 0.094 & 0.227 & 0.511 & 0.841 & 0.461 & 0.595 \\
AMF & $\mathbf{0 . 0 0 2} \mathbf{1}$ & $\mathbf{0 . 0 0 1}$ & 0.144 & 0.782 & 0.475 & 0.985 & 0.894 \\
Serendipita $\times$ AMF & 0.085 & $\mathbf{0 . 0 1 2}$ & 0.136 & 0.061 & $\mathbf{0 . 0 1 4}$ & $\mathbf{0 . 0 0 1}$ & $\mathbf{0 . 0 0 0}$ \\
\hline
\end{tabular}

${ }^{1}$ Significant values $(p<0.05)$ are highlighted in bold.

Although the factor, AMF, significantly affected the calcium concentration in tomato shoots $\left(F_{(1,18)}=16.819, p=0.001\right)$, this effect was not exclusive since the Serendipita $\times$ AMF interaction was also observed to be significant $\left(F_{(2,18)}=20.988, p=0.012\right)$ (Table 4$)$. This interaction effect manifested as a 20\% increase in Ca concentration in S. indica compared to $S$. williamsii but not compared to the control uninoculated plants in the -AMF treatment (Figure $4 b$ ). 

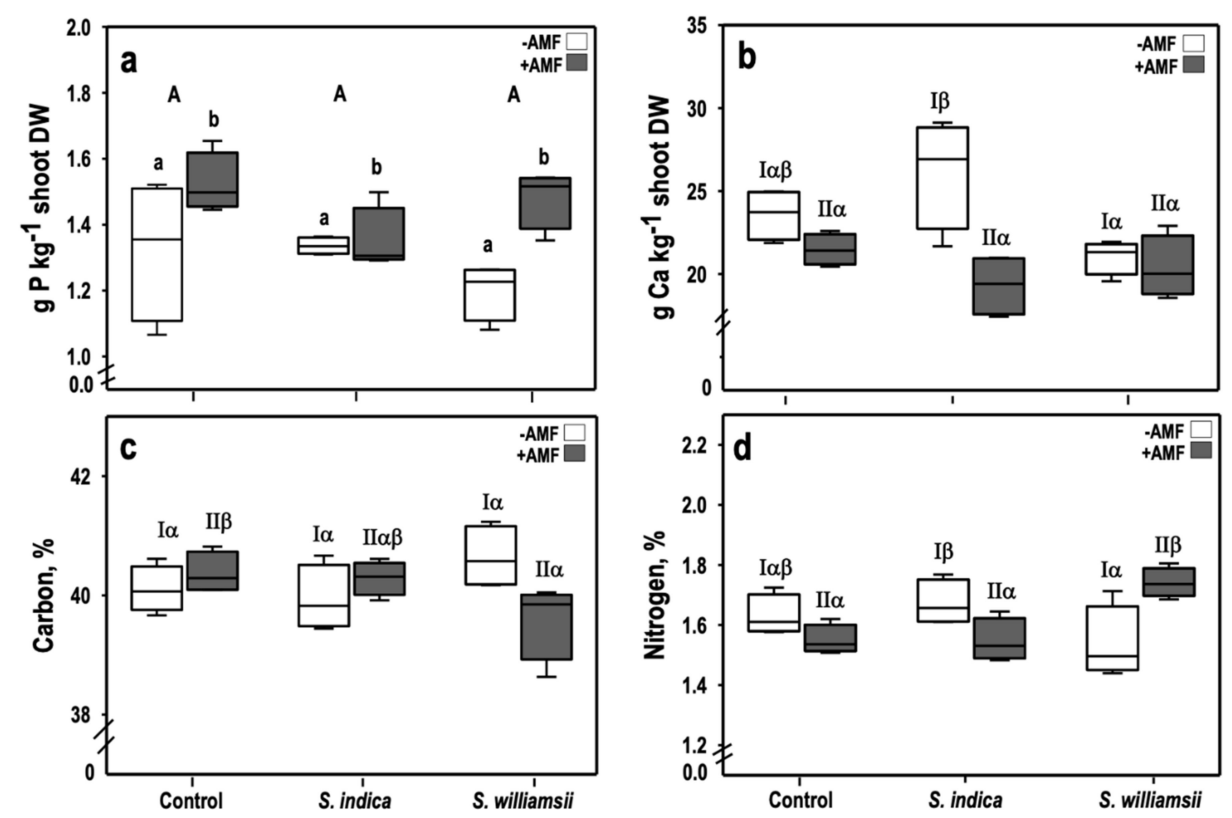

Figure 4. Macronutrient concentration in tomato shoots nine weeks after transplanting: phosphorus (a) and calcium (b) (in g. $\mathrm{kg}^{-1}$ shoot dry weight) and carbon (c) and nitrogen (d) (in \%). Upper-case letters indicate differences in the main factor 'Serendipita'. Lower-case letters indicate differences in the main factor 'AMF' (ANOVA, $p<0.05$, $n=4)$. Greek letters were used to highlight significant interaction effects based on the simple effect analysis for $-\mathrm{AMF}(\mathrm{I})$ and $+\mathrm{AMF}(\mathrm{II})$. Columns followed by the same letters are not significantly different.

Both carbon and nitrogen, were unaffected by the main factors AMF and Serendipita (Table 4). Nevertheless, these two elements were influenced by the Serendipita $\times$ AMF interactions $\left(F_{(2,18)}=5.414\right.$, $p=0.014)$ and $\left(F_{(2,18)}=11.008, p=0.001\right)$, respectively. For carbon, a significant interaction was found in the + AMF treatments (Figure 4c). Specifically, a reduction was observed between the control plants $(40.37 \pm 0.35 \%)$ and the S. williamsii + AMF inoculated plants $(39.60 \% \pm 0.65)$. For nitrogen, a significant interaction occurred in both the $-\mathrm{AMF}$ and + AMF treatments. In the -AMF treatment, a significant interaction was noticeable as an increase of $\mathrm{N}$ in $\mathrm{S}$. indica $(1.67 \pm 0.08 \%)$ compared to $S$. williamsii $(1.54 \pm 0.12 \%)$ inoculated plants (Figure $4 \mathrm{~d}$ ) but not in comparison to the control untreated plants. In the $+\mathrm{AMF}$ treatment, co-inoculation with S. williamsii $+\mathrm{AMF}$ resulted in an increase in $\mathrm{N}(1.74 \pm 0.05 \%)$ as compared to both the control $(1.55 \pm 0.05 \%)$ and S. indica $+\operatorname{AMF}(1.55 \pm 0.07 \%)$ plants.

The $\mathrm{CN}$ ratio was significantly influenced by the Serendipita $\times \mathrm{AMF}$ interaction $\left(F_{(2,18)}=12.369, p=0.000\right)$ (Table 4). This interaction was apparent between the +AMF plants (Figure 5). Specifically, the CN ratio was reduced by $13 \%$ when $S$. williamsii was combined with AMF compared to the control mycorrhizal plants.

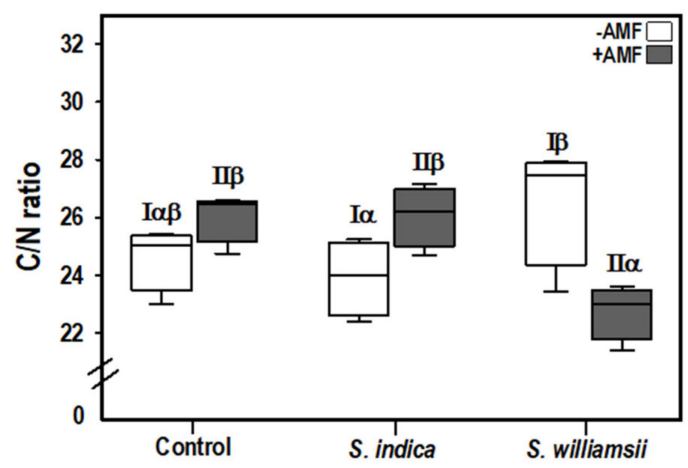

Figure 5. Carbon to nitrogen ratio $(\mathrm{C} / \mathrm{N})$ in the tomato shoots nine weeks after transplanting. (ANOVA, $p<0.05$, $n=4)$. Greek letters were used to highlight significant interaction effects based on the simple effect analysis for $-\mathrm{AMF}(\mathrm{I})$ and +AMF(II). 


\subsubsection{Micronutrients}

The manganese $(\mathrm{Mn})$ concentration in tomato shoots was significantly affected by the main factor $\operatorname{AMF}\left(F_{(1,18)}=37.199, p=0.000\right)$ (Table 5). This manifested as a $33 \%$ reduction of $\mathrm{Mn}$ in the $+\mathrm{AMF}$ compared to the $-\mathrm{AMF}$ treated plants (Figure 6a).

Table 5. Results of the two-way ANOVA ( $p$-values) for micronutrient concentration in the tomato shoots nine weeks after transplanting with the factors 'Serendipita' , 'AMF', and 'Serendipita $\times$ AMF' interactions $(p<0.05, n=4)$.

\begin{tabular}{cccc}
\hline \multirow{2}{*}{ Treatments } & \multicolumn{3}{c}{ Micronutrients } \\
\cline { 2 - 4 } & $\mathbf{M n}$ & $\mathbf{F e}$ & $\mathbf{Z n}$ \\
\hline Serendipita & 0.554 & 0.612 & 0.306 \\
AMF & $\mathbf{0 . 0 0 0} \mathbf{1}^{\mathbf{1}}$ & $\mathbf{0 . 0 0 0}$ & 0.720 \\
Serendipita $\times$ AMF & 0.086 & 0.345 & 0.176 \\
\hline
\end{tabular}

${ }^{1}$ Significant values $(p<0.05)$ are highlighted in bold.
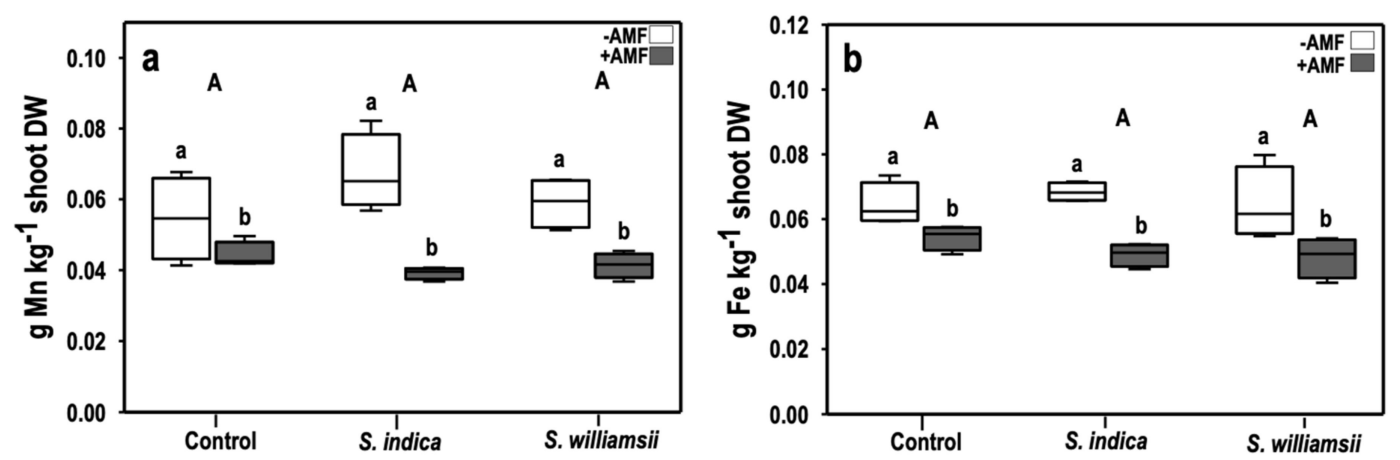

Figure 6. Manganese (a) and iron (b) concentrations (in $\mathrm{g} \cdot \mathrm{kg}^{-1}$ shoot dry weight) in tomato shoots nine weeks after transplanting. Upper-case letters indicate the differences in the main factor 'Serendipita'. Lower-case letters indicate the differences in the main factor 'AMF'. Columns followed by the same letters are not significantly different (ANOVA, $p<0.05, n=4$ ).

The iron concentration in the tomato shoots was also considerably affected by the main factor AMF $\left(F_{(1,18)}=34.548, p=0.000\right)$ (Table 5$)$. This was characterized as a $22 \%$ reduction of Fe in the +AMF compared to the $-\mathrm{AMF}$ treated plants (Figure $6 \mathrm{~b}$ ). The zinc concentrations in the tomato shoots were similar under all treatments (Table 5).

\subsection{Correlation between Nutrients and AMF Root Colonization}

Among all analyzed nutrients, only phosphorus was drawn towards the same axis with $\mathrm{AM}_{F}$ root colonization while the other nutrients, particularly manganese and iron, were negatively correlated (Figure 7). In addition, all samples treated with AMF were correlated with phosphorus and AMF root colonization parameters (e.g., total colonization (TC), arbuscular colonization (Ar), and vesicular colonization $(\mathrm{Vc}))$. S. indica + AMF plants shared the same cluster with AMF plants, while S. williamsii + AMF was found in a different group. All non-mycorrhizal treatments were located on the opposite side of the axis and were more similar in terms of other nutrients such as $\mathrm{Ca}, \mathrm{Mn}, \mathrm{Fe}$, and $\mathrm{Zn}$. 


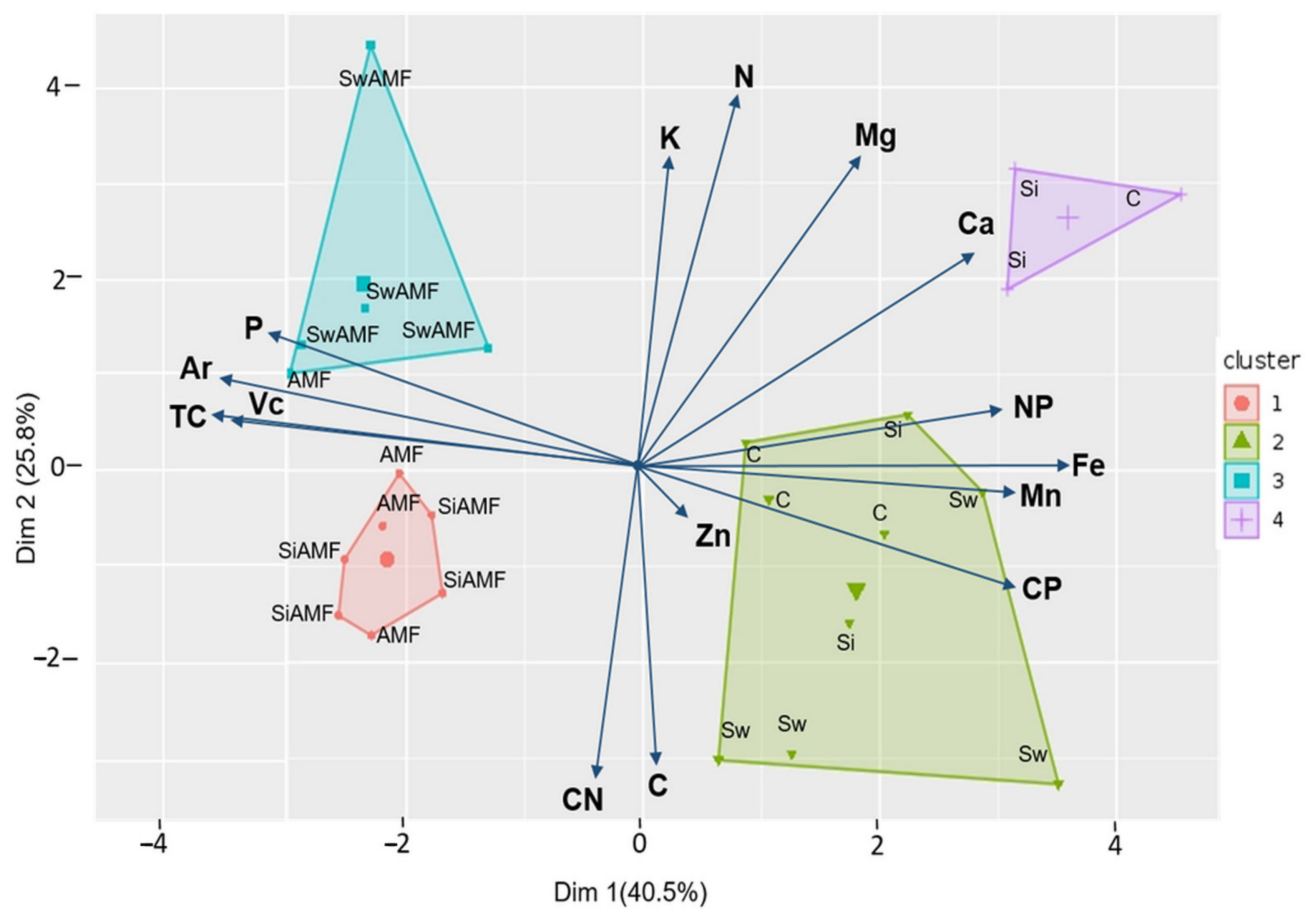

Figure 7. Principal component analysis of tomato samples with regards to macro and micronutrient concentrations in tomato shoots, as well as AMF colonization in the roots. The first two axes represent 40.5 and $25.8 \%$ variation in the data. Nutrient variables include potassium $(\mathrm{K})$, nitrogen $(\mathrm{N})$, magnesium $(\mathrm{Mg})$, calcium (Ca), nitrogen to phosphorus ratio (NP), iron (Fe), manganese (Mn), carbon to phosphorus ratio $(\mathrm{CP})$, zinc $(\mathrm{Zn})$, carbon $(\mathrm{C})$, carbon to nitrogen ratio $(\mathrm{CN})$, and phosphorus $(\mathrm{P})$. The AMF root colonization parameters include total colonization (TC), arbuscular colonization (Ar), and vesicular colonization (Vc). Data points represent the treatments including the control (C), Si (S. indica), Sw (S. williamsii), and arbuscular mycorrhizal fungi (AMF).

\section{Discussion}

In our study, we demonstrated that the root endophytes Serendipita indica and S. williamsii coexist with the arbuscular mycorrhizal fungus F. mosseae in tomato roots, as shown via microscopic and molecular analyses. The simultaneous presence of either S. indica or S. williamsii did not affect the AMF colonization parameters in tomato plants. This outcome might be due to the different colonization strategies and niche preferences among the endophytic and mycorrhizal fungi. It was reported that $S$. indica can develop even in dead host cells [47], while AMF can only proliferate in living host tissue [10]. These characteristics indicate less competition for space and resources, giving each other a venue to coexist. The association between Serendipita and AMF was previously emphasized in two independent studies. In an earlier study, Williams [21] detected chlamydospores of $S$. williamsii in the intracellular structure of an AM fungus and he found positive growth effects when AMF was added to the plant-endophyte system. Several decades later, Venneman et al. [4] observed the frequent coexistence between Serendipita isolates and AMF in the roots of sudangrass but they did not investigate the potential effects of the combined inoculation in plants. In our research, the introduction of $S$. williamsii to AM tomato plants did not affect AMF root colonization, indicating that it may occupy a niche in the root similar to $S$. indica. The absence of adverse effects on AMF colonization upon inoculation with Serendipita spp. suggests the possibility of coexistence, proving the feasibility of their combination for future agronomic uses. However, variable amounts of $S$. indica inoculum and different inoculation methods caused a decline in AMF root colonization in tomato [35], but an increase of this parameter in mycorrhizal sweet basil plants [33]. This indicates that, to a certain extent, the amount of inoculum, the method of inoculation, the stage of colonization, and the plant and mycorrhizal species dictate the function of the tripartite interaction, but this relationship requires further confirmation. 
Growth in tomato plants was unaffected following single or dual inoculation with Serendipita spp. and AMF. Even though we used a low nutrient regime in our study, we did not observe a negative growth response, especially as both mycorrhizal and endophytic fungi can compete with plants for nutrients and other resources [14,48-50]. Contrary to our results, a combination of S. indica or S. williamsii and AM fungus R. irregularis increased growth in sweet basil [33] and pasture legumes [21], respectively. Several factors, such as the variabilities in the experimental set-up, environmental conditions, and plant species likely contributed to these disparities, as has been shown in other studies [22,24]. Nevertheless, the AM tomato plants showed higher photosynthetic activity than their non-mycorrhizal counterparts. AM fungi play a role in improving the function of photosystem II through stabilizing electron transport at both the receptor and donor sides [51]. The higher photosynthetic activity in the AM plants did not reflect growth enhancement because a substantial amount of photosynthates was also supplied to the fungal symbiont to maintain their mycorrhizal networks and complete their life cycles [11,14].

The addition of AMF considerably increased the phosphorus (P) concentration in the AM tomato plants compared to their non-mycorrhizal counterparts. Positive effects of AMF inoculation on P status in tomato plants was also shown in the study of Hart et al. [52]. Phosphorus is an essential nutrient required for various biological and chemical processes in plants [53]. However, it is poorly available in the soil [10], which poses a challenge to crop production systems. The use of biological agents such as AMF is among the most well-recognized measures to improve P bioavailability [14]. Mycorrhizal hyphae can penetrate the soil more efficiently than plant roots [54,55], thus making AMF an undisputable fungal partner in enhancing nutritional status in plants. In contrast to AMF, the role of Serendipita spp. in plant $P$ nutrition is still controversial [56]. For instance, some authors reported the absence of $P$ stimulating factor of S. indica in tobacco [25], barley [23], chickpea, [57] and potato [58], similar to our findings. Due to the inability of this endophyte to affect $P$ status in plants, several studies were focused on the combinatory effects of S. indica and potential phosphate solubilizing bacteria (PSB) [56,59]. Interestingly, S. indica was found to host an endobacterium called Rhizobium radiobacter [60], whose role in the tripartite interaction is not yet fully understood [61]. Nevertheless, other authors showed a positive outcome on P uptake after inoculating plants with S. indica [62-64], the underlying mechanism of which could include the lowering of $\mathrm{pH}$ through the production of organic acids [65], stimulating acid phosphatase activity [63], and inducing high affinity phosphate transporter genes, especially under phosphate deprived conditions [64]. It is not known whether S. williamsii can affect P status in plants, but our findings suggest that it acts similar to $S$. indica; it inhabits the roots next to the AMF without altering the phosphate stimulating function of the latter.

To the best of our knowledge, this is the first study that exhibits the synergistic effects of Serendipita spp. and $\mathrm{AMF}$ on the $\mathrm{CN}$ dynamics in tomato plants. Specifically, the addition of $S$. williamsii boosted the $\mathrm{N}$ concentration in AM tomato shoots. Soil microorganisms play a vital role in both the immobilization and mineralization of organic nitrogen [66] and the nitrification or denitrification of inorganic $\mathrm{N} \mathrm{[10].}$ Unlike phosphate, nitrogen sources such as nitrate and ammonium are relatively mobile in the soil; thus, plant roots take them up even in a non-mycorrhizal state [10]. Nevertheless, the impact of AMF in influencing $\mathrm{N}$ uptake has received much attention recently [67]. For example, some authors showed an increase of nitrogen in AM tomato plants due to elevated levels of amino acids [68], which are crucial for $\mathrm{N}$ uptake in mycorrhizal symbiosis [69]. Conversely, other authors reported negative effects of AMF in plant $\mathrm{N}$ acquisition, which might be due to fungal $\mathrm{N}$ retention $[9,70,71]$. AM fungi require nitrogen for their growth and maintenance, and, under a limited $\mathrm{N}$ supply, the fungus acts as the first $\mathrm{N}$ sink [72]. As a consequence, $\mathrm{AMF}$ provides the host plant with surplus $\mathrm{N}[73,74]$. In our experimental system, we assume that the mycorrhizal fungi can serve as an $\mathrm{N}$ sink and that the presence of $S$. williamsii ameliorates the process such that a considerable amount of $\mathrm{N}$ is transferred to the plant. In addition, the increase of nitrogen in the S. williamsii + AMF treated plants was compensated with the carbon cost. Fellbaum et al. [75] showed that carbon availability significantly triggers nitrogen uptake and transport in AM plants. We also cannot rule out the possibility that AMF can become parasitic in this type of system because mycorrhizal fungi are considered to be a major sink for photosynthates $[14,48]$. Although S. indica and AMF coexisted, their interactions did not alter the CN dynamics 
in tomato plants. The work of Zucarro et al. [76] provided insights into the genome of $S$. indica and revealed the absence of genes that encode for the uptake and reduction of nitrate. Therefore, $S$. williamsii potentially performs differently from $S$. indica when co-inoculated with AMF, which points to an unknown mechanism that needs more detailed investigation.

Single inoculation with S. indica enhanced calcium (Ca) concentration in tomato shoot in comparison to the S. williamsii treated plants, although it was not significantly different from the control untreated plants. Calcium is relatively mobile in the soil, but the presence of $S$. indica might be an important strategy to enhance Ca uptake by plants especially in Ca deficient soils.

In our experiment, we observed a consistent decline in manganese and iron in mycorrhizal tomato plants. AMF has been reported to reduce the microbial communities responsible for $\mathrm{Mn}^{+\mathrm{IV}}$ reducing potential, thereby decreasing Mn stimulating activity in the soil [77]. Other authors showed the ability of AMF to regulate higher concentrations of micronutrients by sequestering Mn granules [78]. Iron is poorly soluble in the soil, and a common strategy developed by fungi to efficiently take up this element involves the secretion of siderophores [79]. The effects of AMF on iron accumulation in plants may also vary depending on the inoculation method. For example, AMF mixed with the substrate resulted in greater Fe accumulation in the tomato shoots, but the element was reduced when the inoculum was added under the seedlings [80]. It was also highlighted that AMF can increase the concentrations of certain elements in the roots but decrease the transport to the shoots $[10,81,82]$, possibly due to sequestration in the hyphae [83]. Inoculation with S. indica alone resulted in increased Fe concentrations in lettuce leaves under nutrient deficient soil [84], as well as in wheat under nutrient sufficient conditions [85]. Interestingly, the combination of S. indica and Azotobacter chroococcum decreased the Fe concentration in wheat plants, which can be attributed to the lesser tolerance of the bacterial partner to nutrient deficiency [85]. Moreover, we cannot exclude the fact that the presence of both endophytic and mycorrhizal fungi in the roots could also entail competition of the micronutrients with their plant partner.

\section{Conclusions}

To summarize, we confirmed the coexistence of root endophytic Serendipita spp. and arbuscular mycorrhizal fungus F. mosseae in tomato roots. Furthermore, we found a highly dynamic relationship between S. williamsii and AMF: This combination enhances the nitrogen concentration in tomato shoot without compromising the phosphorus stimulating function of AMF. This synergistic effect offers new insight into the use of microbial combinations to enhance nutrient acquisition in plants. However, the optimum amount of inoculum and the method of inoculation for both endophytic and mycorrhizal fungi must be investigated in to maximize the potential of their combination. Moreover, we observed that S. williamsii performs differently from S. indica when co-inoculated with AMF, indicating an unknown mechanism that needs further studies.

Author Contributions: Conceptualization, K.H.-A.; methodology, K.H.-A. and A.M.H.; formal analysis, A.M.H., B.S., and K.H.-A.; investigation, A.M.H.; writing-original draft preparation, A.M.H. and K.H.-A.; writing-review and editing, A.M.H., B.S., S.S., and K.H.-A.; visualization, A.M.H. and K.H.-A.; supervision, S.S. and K.H.-A.; project administration, K.H.-A.; funding acquisition, K.H.-A. All authors have read and agreed to the published version of the manuscript.

Funding: This research was funded by the Austrian Science Fund (FWF) (P30051-B32).

Acknowledgments: We acknowledge the technical support by the Department of Soil Science and the Department of Crop Sciences, BOKU, Vienna, Austria, for the nutrient analysis and C/N analysis, respectively. We thank Michael Weiß (University of Tübingen, Germany) for kindly providing S. williamsii (DAR 29830). We thank Karin Baumgartner, Sabine Daxböck-Horvath, and Tina Austerlitz for their excellent technical assistance.

Conflicts of Interest: The authors declare no conflict of interest. 


\section{References}

1. Franken, P. The plant strengthening root endophyte Piriformospora indica: Potential application and the biology behind. Appl. Microbiol. Biotechnol. 2012, 96, 1455-1464. [CrossRef]

2. Philippot, L.; Raaijmakers, J.M.; Lemanceau, P.; Van Der Putten, W.H. Going back to the roots: The microbial ecology of the rhizosphere. Nat. Rev. Microbiol. 2013, 11, 789-799. [CrossRef]

3. Whipps, J.M. Microbial interactions and biocontrol in the rhizosphere. J. Exp. Bot. 2001, 52, 487-511. [CrossRef]

4. Venneman, J.; Audenaert, K.; Verwaeren, J.; Baert, G.; Boeckx, P.; Moango, A.M.; Dhed'a, B.D.; Vereecke, D.; Haesaert, G. Congolese rhizospheric soils as a rich source of new plant growth-promoting endophytic Piriformospora isolates. Front. Microbiol. 2017, 8, 212. [CrossRef] [PubMed]

5. Rodriguez, R.; White, J., Jr.; Arnold, A.E.; Redman, A.R.A. Fungal endophytes: Diversity and functional roles. New Phytol. 2009, 182, 314-330. [CrossRef] [PubMed]

6. Bajaj, R.; Huang, Y.; Gebrechristos, S.; Mikolajczyk, B.; Brown, H.; Prasad, R.; Varma, A.; Bushley, K.E. Transcriptional responses of soybean roots to colonization with the root endophytic fungus Piriformospora indica reveals altered phenylpropanoid and secondary metabolism. Sci. Rep. 2018, 8, 1-18. [CrossRef] [PubMed]

7. Blaalid, R.; Carlsen, T.O.R.; Kumar, S.; Halvorsen, R.; Ugland, K.I.; Fontana, G.; Kauserud, H. Changes in the root-associated fungal communities along a primary succession gradient analysed by 454 pyrosequencing. Mol. Ecol. 2012, 21, 1897-1908. [CrossRef] [PubMed]

8. Detheridge, A.P.; Brand, G.; Fychan, R.; Crotty, F.V.; Sanderson, R.; Griffith, G.W.; Marley, C.L. The legacy effect of cover crops on soil fungal populations in a cereal rotation. Agric. Ecosyst. Environ. 2016, 228, 49-61. [CrossRef]

9. Correa, A.; Cruz, C.; Perez-Tienda, J.; Ferrol, N. Shedding light onto nutrient responses of arbuscular mycorrhizal plants: Nutrient interactions may lead to unpredicted outcomes of the symbiosis. Plant Sci. 2014, 221, 29-41. [CrossRef]

10. Smith, S.E.; Read, D.J. Mycorrhizal Symbiosis; Academic Press: Cambridge, MA, USA, 2008.

11. Bago, B.; Pfeffer, P.E.; Shachar-Hill, Y. Carbon metabolism and transport in arbuscular mycorrhizas. Plant Physiol. 2000, 124, 949-958. [CrossRef]

12. Bonfante, P.; Genre, A. Mechanisms underlying beneficial plant-fungus interactions in mycorrhizal symbiosis. Nat. Commun. 2010, 1, 1-11. [CrossRef] [PubMed]

13. Clark, R.á.; Zeto, S. Mineral acquisition by arbuscular mycorrhizal plants. J. Plant Nutr. 2000, 23, 867-902. [CrossRef]

14. Marschner, P. Rhizosphere biology. In Marschner's Mineral Nutrition of Higher Plants; Elsevier: Amsterdam, The Netherlands, 2012; pp. 369-388.

15. Zitterl-Eglseer, K.; Nell, M.; Lamien-Meda, A.; Steinkellner, S.; Wawrosch, C.; Kopp, B.; Zitterl, W.; Vierheilig, H.; Novak, J. Effects of root colonization by symbiotic arbuscular mycorrhizal fungi on the yield of pharmacologically active compounds in Angelica archangelica L. Acta Physiol. Plant 2015, 37. [CrossRef]

16. Cesaro, P.; Massa, N.; Cantamessa, S.; Todeschini, V.; Bona, E.; Berta, G.; Barbato, R.; Lingua, G. Tomato responses to Funneliformis mosseae during the early stages of arbuscular mycorrhizal symbiosis. Mycorrhiza 2020, 30, 601-610. [CrossRef]

17. Khaosaad, T.; Garcia-Garrido, J.M.; Steinkellner, S.; Vierheilig, H. Take-all disease is systemically reduced in roots of mycorrhizal barley plants. Soil Biol. Biochem. 2007, 39, 727-734. [CrossRef]

18. Steinkellner, S.; Hage-Ahmed, K.; Garcia-Garrido, J.M.; Illana, A.; Ocampo, J.A.; Vierheilig, H. A comparison of wild-type, old and modern tomato cultivars in the interaction with the arbuscular mycorrhizal fungus Glomus mosseae and the tomato pathogen Fusarium oxysporum $\mathrm{f}$. sp lycopersici. Mycorrhiza 2012, 22, 189-194. [CrossRef]

19. Verma, S.; Varma, A.; Rexer, K.H.; Hassel, A.; Kost, G.; Sarbhoy, A.; Bisen, P.; Butehorn, B.; Franken, P. Piriformospora indica, gen. et sp. nov., a new root-colonizing fungus. Mycologia 1998, 90, 896-903. [CrossRef]

20. Varma, S.; Verma, A.; Sahay, N.; Butehorn, B.; Franken, P. Piriformospora indica, a cultivable plant-growth-promoting root endophyte. Appl. Environ. Microbiol. 1999, 65, 2741-2744. [CrossRef] [PubMed]

21. Williams, P.G. Orchidaceous rhizoctonias in pot cultures of vesicular arbuscular mycorrhizal fungi. Can. J. Bot. Rev. Can. Bot. 1985, 63, 1329-1333. [CrossRef]

22. Sefloo, N.G.; Wieczorek, K.; Steinkellner, S.; Hage-Ahmed, K. Serendipita species trigger cultivar-specific responses to fusarium wilt in tomato. Agronomy 2019, 9, 595. [CrossRef]

23. Achatz, B.; von Rueden, S.; Andrade, D.; Neumann, E.; Pons-Kuehnemann, J.; Kogel, K.-H.; Franken, P.; Waller, F. Root colonization by Piriformospora indica enhances grain yield in barley under diverse nutrient regimes by accelerating plant development. Plant Soil 2010, 333, 59-70. [CrossRef] 
24. Fakhro, A.; Andrade-Linares, D.R.; von Bargen, S.; Bandte, M.; Buettner, C.; Grosch, R.; Schwarz, D.; Franken, P. Impact of Piriformospora indica on tomato growth and on interaction with fungal and viral pathogens. Mycorrhiza 2010, 20, 191-200. [CrossRef] [PubMed]

25. Barazani, O.; Benderoth, M.; Groten, K.; Kuhlemeier, C.; Baldwin, I.T. Piriformospora indica and Sebacina vermifera increase growth performance at the expense of herbivore resistance in Nicotiana attenuata. Oecologia 2005, 146, 234-243. [CrossRef] [PubMed]

26. Cheng, C.; Li, D.; Qi, Q.; Sun, X.; Anue, M.R.; David, B.M.; Zhang, Y.; Hao, X.; Zhang, Z.; Lai, Z. The root endophytic fungus Serendipita indica improves resistance of banana to Fusarium oxysporum $\mathrm{f}$. sp. cubense tropical race 4. Eur. J. Plant Pathol. 2020, 156, 87-100. [CrossRef]

27. Cosme, M.; Lu, J.; Erb, M.; Stout, M.J.; Franken, P.; Wurst, S. A fungal endophyte helps plants to tolerate root herbivory through changes in gibberellin and jasmonate signaling. New Phytol. 2016, 211, 1065-1076. [CrossRef]

28. Kumar, M.; Yadav, V.; Tuteja, N.; Johri, A.K. Antioxidant enzyme activities in maize plants colonized with Piriformospora indica. Microbiology. 2009, 155, 780-790. [CrossRef]

29. Narayan, O.P.; Verma, N.; Singh, A.K.; Oelmueller, R.; Kumar, M.; Prasad, D.; Kapoor, R.; Dua, M.; Johri, A.K. Antioxidant enzymes in chickpea colonized by Piriformospora indica participate in defense against the pathogen Botrytis cinerea. Sci. Rep. 2017, 7. [CrossRef]

30. Rabiey, M.; Ullah, I.; Shaw, M. The endophytic fungus Piriformospora indica protects wheat from fusarium crown rot disease in simulated UK autumn conditions. Plant Pathol. 2015, 64, 1029-1040. [CrossRef]

31. Dabral, S.; Yashaswee; Varma, A.; Choudhary, D.K.; Bahuguna, R.N.; Nath, M. Biopriming with Piriformospora indica ameliorates cadmium stress in rice by lowering oxidative stress and cell death in root cells. Ecotoxicol. Environ. Saf. 2019, 186. [CrossRef]

32. Hosseini, F.; Mosaddeghi, M.R.; Dexter, A.R. Effect of the fungus Piriformospora indica on physiological characteristics and root morphology of wheat under combined drought and mechanical stresses. Plant Physiol. Biochem. 2017, 118, 107-120. [CrossRef]

33. Sabra, M.; Aboulnasr, A.; Franken, P.; Perreca, E.; Wright, L.P.; Camehl, I. Beneficial root endophytic fungi increase growth and quality parameters of sweet basil in heavy metal contaminated soil. Front. Plant Sci. 2018, 9. [CrossRef] [PubMed]

34. Zhang, W.; Wang, J.; Xu, L.; Wang, A.; Huang, L.; Du, H.; Qiu, L.; Oelmueller, R. Drought stress responses in maize are diminished by Piriformospora indica. Plant Signal. Behav. 2018, 13. [CrossRef]

35. Heidarianpour, M.B.; Aliasgharzad, N.; Olsson, P.A. Positive effects of co-inoculation with Rhizophagus irregularis and Serendipita indica on tomato growth under saline conditions, and their individual colonization estimated by signature lipids. Mycorrhiza 2020, 30, 455-466. [CrossRef] [PubMed]

36. Hill, T.W.; Kafer, E. Improved protocols for Aspergillus minimal medium: Trace element and minimal medium salt stock solutions. Fungal Genet. Rep. 2001, 48, 20-21. [CrossRef]

37. Vierheilig, H.; Coughlan, A.P.; Wyss, U.; Piché, Y. Ink and vinegar, a simple staining technique for arbuscular-mycorrhizal fungi. Appl. Environ. Microbiol. 1998, 64, 5004-5007. [CrossRef] [PubMed]

38. Koide, R.; Elliott, G. Cost, benefit and efficiency of the vesicular-arbuscular mycorrhizal symbiosis. Funct. Ecol. 1989, 3, 252-255. [CrossRef]

39. Steineck, O. Nährlösungen der Pflanzenkultur. Bodenkultur 1951, 5, 313-324.

40. Dumas, J.B.A. Procédés de l'analyse organique. Ann. Chem. Phys. 1831, 47, 198-213.

41. McGonigle, T.; Miller, M.; Evans, D.; Fairchild, G.; Swan, J. A new method which gives an objective measure of colonization of roots by vesicular-Arbuscular mycorrhizal fungi. New Phytol. 1990, 115, 495-501. [CrossRef]

42. Ye, J.; Coulouris, G.; Zaretskaya, I.; Cutcutache, I.; Rozen, S.; Madden, T.L. Primer-BLAST: A tool to design target-specific primers for polymerase chain reaction. BMC Bioinform. 2012, 13, 134. [CrossRef]

43. Carbone, I.; Kohn, L.M. A method for designing primer sets for speciation studies in filamentous ascomycetes. Mycologia 1999, 91, 553-556. [CrossRef]

44. Stielow, J.B.; Lévesque, C.A.; Seifert, K.A.; Meyer, W.; Iriny, L.; Smits, D.; Renfurm, R.; Verkley, G.J.; Groenewald, M.; Chaduli, D.; et al. One fungus, which genes? Development and assessment of universal primers for potential secondary fungal DNA barcodes. Persoonia 2015, 35, 242-263. [CrossRef] [PubMed]

45. Basiewicz, M.; Weiss, M.; Kogel, K.-H.; Langen, G.; Zorn, H.; Zuccaro, A. Molecular and phenotypic characterization of Sebacina vermifera strains associated with orchids, and the description of Piriformospora williamsii sp. nov. Fungal Biol. 2012, 116, 204-213. [CrossRef] [PubMed] 
46. Kalaji, H.M.; Jajoo, A.; Oukarroum, A.; Brestic, M.; Zivcak, M.; Samborska, I.A.; Cetner, M.D.; Łukasik, I.; Goltsev, V.; Ladle, R.J. Chlorophyll a fluorescence as a tool to monitor physiological status of plants under abiotic stress conditions. Acta Physiol. Plant 2016, 38, 102. [CrossRef]

47. Deshmukh, S.; Hückelhoven, R.; Schäfer, P.; Imani, J.; Sharma, M.; Weiss, M.; Waller, F.; Kogel, K.-H. The root endophytic fungus Piriformospora indica requires host cell death for proliferation during mutualistic symbiosis with barley. Proc. Natl. Acad. Sci. USA 2006, 103, 18450-18457. [CrossRef] [PubMed]

48. Douds, D.D.; Johnson, C.R.; Koch, K.E. Carbon cost of the fungal symbiont relative to net leaf P accumulation in a split-root VA mycorrhizal symbiosis. Plant Physiol. 1988, 86, 491-496. [CrossRef] [PubMed]

49. Rousk, J.; Bååth, E.; Göransson, H.; Fransson, A.-M. Assessing plant-microbial competition for 33P using uptake into phospholipids. Appl. Soil Ecol. 2007, 36, 233-237. [CrossRef]

50. Zhang, L.; Fan, J.; Ding, X.; He, X.; Zhang, F.; Feng, G. Hyphosphere interactions between an arbuscular mycorrhizal fungus and a phosphate solubilizing bacterium promote phytate mineralization in soil. Soil Biol. Biochem. 2014, 74, 177-183. [CrossRef]

51. Zhang, H.; Xu, N.; Li, X.; Long, J.; Sui, X.; Wu, Y.; Li, J.; Wang, J.; Zhong, H.; Sun, G.Y. Arbuscular mycorrhizal fungi (Glomus mosseae) improves growth, photosynthesis and protects photosystem II in leaves of Lolium perenne L. in cadmium contaminated soil. Front. Plant Sci. 2018, 9, 1156. [CrossRef]

52. Hart, M.; Ehret, D.L.; Krumbein, A.; Leung, C.; Murch, S.; Turi, C.; Franken, P. Inoculation with arbuscular mycorrhizal fungi improves the nutritional value of tomatoes. Mycorrhiza 2015, 25, 359-376. [CrossRef] [PubMed]

53. Raghothama, K. Phosphate acquisition. Annu. Rev. Plant Biol. 1999, 50, 665-693. [CrossRef]

54. Tinker, P.; Jones, M.; Durall, D. A functional comparison of ecto-and endomycorrhizas. In Mycorrhizas in Ecosystems; CAB International: Walingford, UK, 1992; pp. 303-310.

55. Lambers, H.; Chapin, F.S., III; Pons, T.L. Plant Physiological Ecology; Springer Science \& Business Media: Berlin, Germany, 2008.

56. Del Barrio-Duque, A.; Ley, J.; Samad, A.; Antonielli, L.; Sessitsch, A.; Compant, S. Beneficial endophytic bacteria-Serendipita indica interaction for crop enhancement and resistance to phytopathogens. Front. Microbiol. 2019, 10, 2888. [CrossRef]

57. Meena, K.K.; Mesapogu, S.; Kumar, M.; Yandigeri, M.S.; Singh, G.; Saxena, A.K. Co-inoculation of the endophytic fungus Piriformospora indica with the phosphate-solubilising bacterium Pseudomonas striata affects population dynamics and plant growth in chickpea. Biol. Fertil. Soils 2010, 46, 169-174. [CrossRef]

58. Karandashov, V.; Nagy, R.; Wegmüller, S.; Amrhein, N.; Bucher, M. Evolutionary conservation of a phosphate transporter in the arbuscular mycorrhizal symbiosis. Proc. Natl. Acad. Sci. USA 2004, 101, 6285-6290. [CrossRef] [PubMed]

59. Sarma, M.; Kumar, V.; Saharan, K.; Srivastava, R.; Sharma, A.; Prakash, A.; Sahai, V.; Bisaria, V. Application of inorganic carrier-based formulations of fluorescent pseudomonads and Piriformospora indica on tomato plants and evaluation of their efficacy. J. Appl. Microbiol. 2011, 111, 456-466. [CrossRef]

60. Sharma, M.; Schmid, M.; Rothballer, M.; Hause, G.; Zuccaro, A.; Imani, J.; Kämpfer, P.; Domann, E.; Schäfer, P.; Hartmann, A. Detection and identification of bacteria intimately associated with fungi of the order Sebacinales. Cell. Microbiol. 2008, 10, 2235-2246. [CrossRef]

61. Glaeser, S.P.; Imani, J.; Alabid, I.; Guo, H.; Kumar, N.; Kämpfer, P.; Hardt, M.; Blom, J.; Goesmann, A.; Rothballer, M. Non-pathogenic Rhizobium radiobacter F4 deploys plant beneficial activity independent of its host Piriformospora indica. ISME J. 2016, 10, 871-884. [CrossRef] [PubMed]

62. Shahollari, B.; Varma, A.; Oelmuller, R. Expression of a receptor kinase in Arabidopsis roots is stimulated by the basidiomycete Piriformospora indica and the protein accumulates in Triton X-100 insoluble plasma membrane microdomains. J. Plant Physiol. 2005, 162, 945-958. [CrossRef] [PubMed]

63. Wu, M.; Wei, Q.; Xu, L.; Li, H.; Oelmüller, R.; Zhang, W. Piriformospora indica enhances phosphorus absorption by stimulating acid phosphatase activities and organic acid accumulation in Brassica napus. Plant Soil 2018, 432, 333-344. [CrossRef]

64. Yadav, V.; Kumar, M.; Deep, D.K.; Kumar, H.; Sharma, R.; Tripathi, T.; Tuteja, N.; Saxena, A.K.; Johri, A.K. A phosphate transporter from the root endophytic fungus Piriformospora indica plays a role in phosphate transport to the host plant. J. Biol. Chem. 2010, 285, 26532-26544. [CrossRef]

65. Ngwene, B.; Boukail, S.; Soellner, L.; Franken, P.; Andrade-Linares, D.R. Phosphate utilization by the fungal root endophyte Piriformospora indica. Plant Soil 2016, 405, 231-241. [CrossRef]

66. McNeill, A.; Unkovich, M. The nitrogen cycle in terrestrial ecosystems. In Nutrient Cycling in Terrestrial Ecosystems; Springer: Berlin, Germany, 2007; pp. 37-64. [CrossRef] 
67. Balestrini, R.; Brunetti, C.; Chitarra, W.; Nerva, L. Photosynthetic traits and nitrogen uptake in crops: Which is the role of arbuscular mycorrhizal fungi? Plants 2020, 9, 1105. [CrossRef] [PubMed]

68. Rivero, J.; Gamir, J.; Aroca, R.; Pozo, M.J.; Flors, V. Metabolic transition in mycorrhizal tomato roots. Front Microbiol. 2015, 6. [CrossRef] [PubMed]

69. Govindarajulu, M.; Pfeffer, P.E.; Jin, H.; Abubaker, J.; Douds, D.D.; Allen, J.W.; Bücking, H.; Lammers, P.J; Shachar-Hill, Y. Nitrogen transfer in the arbuscular mycorrhizal symbiosis. Nature 2005, 435, 819-823. [CrossRef] [PubMed]

70. Johansen, A. Depletion of soil mineral $\mathrm{N}$ by roots of Cucumis sativus L. colonized or not by arbuscular mycorrhizal fungi. Plant Soil 1999, 209, 119-127. [CrossRef]

71. Nouri, E.; Breuillin-Sessoms, F.; Feller, U.; Reinhardt, D. Phosphorus and nitrogen regulate arbuscular mycorrhizal symbiosis in Petunia hybrida. PLoS ONE 2014, 9, e90841. [CrossRef]

72. Nordin, A.; Schmidt, I.K.; Shaver, G.R. Nitrogen uptake by arctic soil microbes and plants in relation to soil nitrogen supply. Ecology 2004, 85, 955-962. [CrossRef]

73. Alberton, O.; Kuyper, T.W.; Gorissen, A. Taking mycocentrism seriously: Mycorrhizal fungal and plant responses to elevated $\mathrm{CO}_{2}$. New Phytol. 2005, 167, 859-868. [CrossRef]

74. Corrêa, A.; Gurevitch, J.; Martins-Loução, M.; Cruz, C. C allocation to the fungus is not a cost to the plant in ectomycorrhizae. Oikos 2012, 121, 449-463. [CrossRef]

75. Fellbaum, C.R.; Gachomo, E.W.; Beesetty, Y.; Choudhari, S.; Strahan, G.D.; Pfeffer, P.E.; Kiers, E.T.; Bücking, H. Carbon availability triggers fungal nitrogen uptake and transport in arbuscular mycorrhizal symbiosis. Proc. Natl. Acad. Sci. USA 2012, 109, 2666-2671. [CrossRef]

76. Zuccaro, A.; Lahrmann, U.; Gueldener, U.; Langen, G.; Pfiffi, S.; Biedenkopf, D.; Wong, P.; Samans, B.; Grimm, C.; Basiewicz, M. Endophytic life strategies decoded by genome and transcriptome analyses of the mutualistic root symbiont Piriformospora indica. PLoS Pathog. 2011, 7. [CrossRef] [PubMed]

77. Kothari, S.; Marschner, H.; Römheld, V. Contribution of the VA mycorrhizal hyphae in acquisition of phosphorus and zinc by maize grown in a calcareous soil. Plant Soil 1991, 131, 177-185. [CrossRef]

78. Turnau, K.; Kottke, I.; Oberwinkler, F. Element localization in mycorrhizal roots of Pteridium aquilinum (L.) Kuhn collected from experimental plots treated with cadmium dust. New Phytol. 1993, 123, 313-324. [CrossRef]

79. Haas, H.; Eisendle, M.; Turgeon, B.G. Siderophores in fungal physiology and virulence. Annu. Rev. Phytopathol. 2008, 46, 149-187. [CrossRef]

80. Bidellaoui, B.; Segarra, G.; Hakkou, A.; Trillas, M.I. Beneficial effects of Rhizophagus irregularis and Trichoderma asperellum strain T34 on growth and fusarium wilt in tomato plants. J. Plant Pathol. 2019, 101, 121-127. [CrossRef]

81. Rufyikiri, G.; Huysmans, L.; Wannijn, J.; Van Hees, M.; Leyval, C.; Jakobsen, I. Arbuscular mycorrhizal fungi can decrease the uptake of uranium by subterranean clover grown at high levels of uranium in soil. Environ. Pollut. 2004, 130, 427-436. [CrossRef] [PubMed]

82. Chen, B.; Roos, P.; Borggaard, O.K.; Zhu, Y.G.; Jakobsen, I. Mycorrhiza and root hairs in barley enhance acquisition of phosphorus and uranium from phosphate rock but mycorrhiza decreases root to shoot uranium transfer. New Phytol. 2005, 165, 591-598. [CrossRef]

83. Christie, P.; Li, X.; Chen, B. Arbuscular mycorrhiza can depress translocation of zinc to shoots of host plants in soils moderately polluted with zinc. Plant Soil 2004, 261, 209-217. [CrossRef]

84. Padash, A.; Shahabivand, S.; Behtash, F.; Aghaee, A. A practicable method for zinc enrichment in lettuce leaves by the endophyte fungus Piriformospora indica under increasing zinc supply. Sci. Hortic. 2016, 213, 367-372. [CrossRef]

85. Abadi, V.A.J.M.; Sepehri, M. Effect of Piriformospora indica and Azotobacter chroococcum on mitigation of zinc deficiency stress in wheat (Triticum aestivum L.). Symbiosis 2016, 69, 9-19. [CrossRef]

Publisher's Note: MDPI stays neutral with regard to jurisdictional claims in published maps and institutional affiliations.

(C) 2020 by the authors. Licensee MDPI, Basel, Switzerland. This article is an open access article distributed under the terms and conditions of the Creative Commons Attribution (CC BY) license (http://creativecommons.org/licenses/by/4.0/). 